\title{
SINTREN DARI SUDUT PANDANG SECONDARY ORALITY
}

Sintren in Form Secondary Orality

Yeni Mulyani Supriatin

Balai Bahasa Jawa Barat

Pos-el: yeni.mulyani1512@gmail.com

\section{Naskah diterima: 11 Maret 2019; direvisi: 21 Desember 2019; disetujui: 23 Desember 2019} DOI: $10.26499 /$ jentera.v8i2.1330

\begin{abstract}
Abstrak: Penelitian ini bertujuan mengungkapkan sintren, sebuah tradisi lisan sebagai primary orality yang bertransformasi dalam bentuk secondary orality. Masalah yang dibahas adalah bagaimana sintren dalam bentuk secondary orality? Apakah benar-benar berubah atau ke luar dari bentuk asalnya? Teori yang digunakan dalam penganalisisan data adalah pendekatan modern dan sudut pandang secondary orality. Metode yang digunakan adalah metode modern dengan teknik perbandingan dan penyimakan. Hasil penelitian menggambarkan bahwa sintren dalam bentuk secondary orality lebih variatif, fungsional, dan lebih menarik, baik dari aspek bentuk maupun tampilannya. Simpulan penelitian ini adalah bahwa secondary orality merupakan satu bentuk penerobosan baru agar sintren sebagai tradisi lisan lebih bertahan, lebih diketahui generasi masa kini, dan lebih bisa menembus zamannya.
\end{abstract}

Kata-kata kunci: sintren, primary orality, dan secondary orality

Abstract: This study aims to reveal sintren as primary orality which is transformed into secondary orality. The problem that is discussed is how does sintren in secondary orality? This research uses a modern approach. The research method applies the principles of the modern approach. The results of the study illustrate that sintren in the form of secondary orality is very different from sintren in the form of primary orality. Sintren in the form of secondary orality varies, functional, and more attractive, both in form and appearance. The conclusion of this research is that secondary orality is a new form of breakthrough so that sintren as an oral tradition is more sustainable, better known to the present generation, and moreable to penetrate its era.

Keywords: sintren, primary orality, and secondary orality

How To Cite: Supriatin, Yeni Mulyani . (2019). Sintren dari Sudut Pandang Secondary Orality. Jentera: Jurnal Kajian Sastra, 8 (2), 188-208. (https://doi.org/10.26499/jentera.v8i2.1330) 


\section{PENDAHULUAN}

Perkembangan teknologi informasi dan media elektronika yang mewarnai kehidupan masyarakat pada saat ini sangat berpengaruh terhadap berbagai ranah bidang ilmu. Tak terkecuali tradisi lisan kita yang pada saat ini keberadaannya sangat dipengaruhi oleh situasi zaman yang terus berubah.

Jika awalnya beberapa tradisi lisan termasuk sintren diselenggarakan sebagai sarana ritual, akhir-akhir ini tradisi lisan tersebut difungsikan juga sebagai sarana hiburan, dan fungsi lain yang disebut sebagai fungsi sekunder. Dasiharjo (2009:10) menjelaskan bahwa fungsi sekunder lebih pada kepentingan yang lain. Artinya, pergelaran tradisi lisan menjadi multifungsi bergantung pada perkembangan pendukungnya, misalnya sebagai pengikat kebersamaan kondisi, media komunikasi, interaksi, ajang gengsi, bisnis (mata pencaharian), dan untuk kepentingan pariwisata.

Dengan perkembangan kondisi seperti ini, tradisi lisan tidak hanya mementingkan ekspresi diri dengan nilai-nilai yang diframe sendiri, tetapi juga harus lebih luas lagi memikirkan kepentingan orang banyak, termasuk promosi daerah yang berkaitan dengan ekonomi untuk pelaku seni dan perkembangan tradisi lisan. Implikasinya, tradisi lisan harus bersinergi dengan aspek lain termasuk kegiatan pariwisata sebagai sektor ekonomi.

Adanya multifungsi ini membuat tradisi lisan tetap terpelihara dan tereksplisitkan sehingga terus dikenal oleh generasi berikutnya. Suryadi (2011:12) mengatakan bahwa di banyak tempat di Indonesia dalam lingkungan budaya yang berbeda-beda, fenomena keterkaitan tradisi lisan dengan media modern makin tampak. Berbagai program televisi sangat merefleksikan tradisi lisan kita.

Genre-genre tradisi lisan kita yang tersimpan dalam bentuk rekaman atau VCD diperjualbelikan. Dengan demikian, peralatan teknologi modern ini dapat memberikan kontribusi untuk merevitalisasi tradisi lisan. Tradisi lisan yang multifungsi dan dalam bentuk rekaman tersebut itulah yang disebut dengan secondary orality.

Tulisan ini memberikan paparan tentang sebuah tradisi lisan yang disebut sintren dalam bentuk secondary orality. Atau, sintren dari sudut pandang secondary orality melalui transformasinya. 
Membicarakan sintren dari sudut pandang secondary orality menjadi menarik karena setiap pembahasan tentu saja tidak terlepas dari sintren dalam bentuk aslinya atau orality primary. Sintren sebagai secondary orality yang dipandang sebagai respons pembaca, penonton, dan penikmat menjadi sangat beragam.

Yang menjadi masalah dalam tulisan ini adalah bagaimana sintren dalam bentuk secondary orality dan bagaimana pula fungsinya? Sementara itu, tujuan tulisan ini adalah memaparkan sintren dalam bentuk secondary orality dan menjelaskan fungsinya. Oleh karena itu, untuk mencapai tujuan itu digunakan teori dan pandangan yang berkaitan dengan secondary orality.

Pengumpulan data dilakukan dengan menelusuri sintren melalui internet, menyimak pertunjukan sintren, mewawancarai penutur sintren dan narasumber. Kemudian, penganalisisan data menggunakan pendekatan modern, sebagaimana dikemukakan oleh Endraswara (2009:76--77) bahwa pendekatan modern memperhatikan unsure folk dan lore dari sintren, tradisi lisan yang akan dikaji. Pendekatan modern lebih bersifat holistik, artinya saat melakukan kajian akan dikaitkan latar belakang atau konteks budaya dengan sintren sehingga hasil kajiannya bersifat emik, yakni melihat folk yang menjadi objek kajian.

\section{LANDASAN TEORI}

\section{Primary Orality dan Secondary Orality}

Ong (1982: 11) mengungkapkan bahwa perkembangan kebudayaan kelisanan tercakup dalam dua bentuk, yakni primary orality dan secondary orality yang ditegaskannya bahwa keduanya berbeda. Primary orality mengacu pada suatu kebudayaan yang sama sekali tidak tersentuh oleh pengetahuan tentang tulismenulis dan cetak-mencetak. Dengan kata lain, primary orality adalah untuk kebudayaan yang sama sekali tidak pernah mengenal tulisan.

Ikram dalam Rahman (2011:3) menjelaskan bahwa primary orality adalah kelisanan yang mengimplikasikan bunyi, memiliki kekhasan bahwa begitu ia ada, begitu pula tiada; sifatnya sesaat, tidak lestari, dan tidak dapat dihentikan. Justru sifatnya yang demikian itu pada bangsa-bangsa tertentu memberi kekuatan magis pada mantra yang harus dihapal tanpa salah supaya efektif. Tidak ada dukun yang melafalkan mantra dengan membacanya dari buku atau tulisan. Dapat dipastikan 
bahwa pada zaman keniraksaraan timbul keperluan untuk mengingat kembali apa yang telah dilisankan terlebih jika itu berupa petuah yang ingin ditransmisikan pada generasi berikutnya. Daya ingat menjadi sangat penting serta sangat dihargai dan diusahakan.

Seiring perkembangan zaman, ketika manusia mengenal budaya tulis yang di Indonesia dikenal pada abad ke-5 sebagaimana dinyatakan oleh Dienaputra dan Ekadjati dalam (Sabana, 2005: 20, 55) bahwa informasi dan pengetahuan yang bersifat lisan dituangkan dalam catatan-catatan agar tidak musnah ditelan zaman. Meskipun sudah menjadi manuskrip karena masih dapat dilantunkan, dituturkan, dipentaskan, ditransmisikan, dan dilisankan, catatan itu dapat digolongkan ke dalam tradisi lisan

Ong (1982:11) menyebut hal itu sebagai tahap orality residu atau 'residu kelisanan'. Dalam tahap ini, tulisan atau catatan yang dilisankan dapat terlihat dan tersentuh oleh siapa saja.

Selanjutnya, berkembangnya teknologi informasi yang luar biasa cepat, pementasan tradisi lisan suka atau tidak suka dengan sendirinya masuk dalam bisnis industri media. Dengan kata lain, kekuatan industri media amat mewarnai wajah tradisi lisan masa kini yang disebut Ong sebagai secondary orality yang menjelaskan bahwa kita sudah masuk dalam kelisanan tahap kedua.

Tradisi lisan tidak lagi tampil ketika penutur bertemu langsung dengan penonton/penikmatnya dalam ruang waktu dan tempat yang sama, tetapi muncul dalam kemasan rekaman video atau kaset yang dapat dihadirkan kapanpun. Ong yang dikutip oleh Venturini, Nielsen, International, \& Dictionary (1983:1) kemudian menyatakan bahwa adanya telepon, radio, televisi, dan berbagai macam pita suara, teknologi elektronik membawa kita pada era secondary orality. Scondary orality secara esensial merupakan suatu kelisanan yang lebih bersifat disengaja dan sadar diri, secara permanen didasarkan pada kegiatan tulis-menulis dan cetak-mencetak.

Situasi secondary orality menurut Pudentia (2008:136) menuntut penikmat atau peneliti tidak harus mempersoalkan mana versi tradisi asli atau yang lengkap. Kehadiran tradisi lisan sebaiknya diterima apa adanya sesuai dengan konsep, prinsip, dan alasan peneliti untuk dipertanggungjawabkan secara akademis. 
Yang menarik adalah melihat kelenturan yang menjadi penanda tradisi lisan dalam pementasannya. Fleksibilitas tradisi lisan merupakan keniscayaan sejauh para penutur dan komunitas pemiliknya menghendaki atau menerimanya. Penelitian ini difokuskan pada sintren sebagai secondary orality sebagaimana dikemukakan oleh Ong.

\section{Pendekatan Modern}

Penelitian ini akan menggunakan pendekatan modern, sebagaimana dikemukakan oleh Danandjaja dalam Pudentia (2008). Menurutnya pendekatan terhadap tradisi lisan ada tiga macam, yakni pendekatan humanistis, pendekatan antropologis, dan pendekatan modern. Pendekatan humanistis lebih memfokuskan diri pada aspek lore daripada folk dalam mengkaji folklore atau tradisi lisan; pendekatan antropologis sebaliknya, yakni lebih memfokuskan diri pada aspek folk; terakhir, pendekatan modern memperhatikan kedua aspek tersebut, yakni folk dan lore dari tradisi lisan yang dikaji. Karena itu, pendekatan modern lebih bersifat holistik, dalam arti waktu melakukan pengkajian akan dikaitkan dengan latar belakang atau konteks kebudayaan tradisi lisan tersebut sehingga hasil kajiannya bersifat emik, yakni juga melihat dari sudut folk yang menjadi objek kajian tradisi lisan (Danandjaja dalam Pudentia, 2008: 61).

Selanjutnya, Danandjaja dalam Pudentia (2008:64) mengemukakan tiga macam pendekatan dalam pendekatan modern, sebagaimana yang dikemukakan oleh Ayu Sutarto dalam disertasinya yang menggunakan pendekatan modern, yaitu 1) pendekatan historis-geografis untuk menyusun kembali, menentukan tempat dan tanggal bentuk dasar suatu cerita rakyat dengan cara membandingkan secara sistematis semua versi yang ada, baik yang sudah ditulis maupun belum ditulis; 2) pendekatan morfologis dari Vladimir Propp yang mengubah fokus studi cerita rakyat dari analisis diakronis menjadi analisis sinkronis. Berbeda dengan analisis historis-geografis yang membandingkan unsur-unsur naratif dari banyak versi yang berasal dari suatu tipe tunggal dalam pembahasan morfologis terhadap cerita rakyat, peneliti menggabungkan unsur-unsur naratif menjadi keseluruhan yang utuh; 3) pendekatan etnografis yang memperluas deskripsi sistematis me ngenai cerita dengan penceritanya, meneliti penceritaan di dalam masyarakat dan kebudayaan. 
Di dalam riset etnografis konsepsi holistik yang merupakan dasar bagi analisis morfologis mencakup sistem bercerita menyeluruh dalam masyarakat.

\section{METODE PENELITIAN}

Penelitian ini menerapkan beberapa cara dalam pengumpulan data. Pertama-tama peneliti mengumpulkan berbagai keterangan yang berkaitan dengan latar belakang yang bersifat sosial dan kebudayaan tentang tradisi lisan yang disebut sintren. Pengumpulan data sintren tersebut dilakukan melalui wawancara oleh peneliti terhadap narasumber dan informan. Yang dimaksud narasumber di sini adalah orang yang mewakili lembaga yang memberikan atau mengetahui secara jelas tentang sintren, sedangkan informan adalah orang yang memberikan informasi tentang sintren. Wawancara antara peneliti dan narasumber tersebut didokumentasikan melalui perekaman. Di samping wawancara, pengumpulan data juga dilakukan melalui pengisian instrumen yang berfungsi sebagai penunjang atau pelengkap data.

Selanjutnya, pentranskripsian data. Hasil wawancara dalam bentuk rekaman tersebut ditranskripsikan. Jika ada yang menggunakan bahasa Sunda atau Jawa, hasil pentranskripsian tersebut diterjemahkan ke dalam bahasa Indonesia.

Langkah berikutnya adalah pengklasifikasian data. Data yang sesuai dengan topik penelitian dikelompokkan menjadi satu. Data yang berasal dari narasumber dan penutur tradisi lisan pada umumnya dipandang sebagai primary orality karena berkaitan dengan sintren sebagai tradisi lisan. Dengan demikian, sintren sebagai primary orality berupa cerita-cerita tentang latar belakang munculnya sintren sampai dengan sintren dalam bentuk pertunjukan.

Triwardani \& Wicandra (2002:2) menjelaskan bahwa budaya kelisanan pertama dan kelisanan kedua memiliki ciri yang khas, yaitu kelisanan pertama berbasis pada fisik manusia, sedangkan kelisanan kedua berbasis pada teknologi. Lebih lanjut Triwardani mengatakan dalam perbedaan tersebut dapat dilihat bahwa perkembangan teknologi komunikasi, khususnya media elektronika memanfaatkan kembali sumber kelisanan sebagai alat penting dalam komunikasi dan penyampaian informasi. 
Karena berbasis teknologi, sintren sebagai secondary orality tersimpan dalam media elektronik, pertunjukan, dan buku-buku. Kemudian, peneliti mengumpulkan sintren dalam bentuk secondary orality. Berkaitan dengan itu, pencarian data sintren sebagai secondary orality, dilakukan melalui internet, dan penelusuran dengan cara studi pustaka.

Setelah data terkumpul, penganalisisan dilakukan secara deskriptis. Selain itu, data juga ditafsirkan dengan cara membandingkan sintren sebagai primary orality dan sintren sebagai secondary orality sehingga akan tampak bagian mana saja yang bertransformasi.

\section{HASIL DAN PEMBAHASAN}

\section{Sintren sebagai Primary Orality}

Bahardur (2018:149) bahwa seni pertunjukan tradisional berawal dari upacara dan ritual keagamaan yang bersifat magis disampaikan dalam bentuk mantra-mantra secara berulang. Upacara dan ritual tersebut menjadi cikal bakal seni pertunjukan tradisional dengan perpaduan unsur gerak dan musik. Demikian pula yang terjadi pada seni pertunjukan sintren.

Ada tiga pendapat tentang arti sintren. Nurlelasari, Herlina, \& Sofi (2017:16), Galba, n.d. (2004:106), dan Kasim (2013: 223, 225) menjelaskan bahwa yang pertama, sintren berasal dari bahasa Belanda, yaitu sinyo trenen, sinyo 'muda', trenen 'berlatih'. Sintren artinya 'seni tempat pemuda berlatih'. Kedua, sintren berasal dari kata sinatria atau ksatria yang merepresentasikan seluruh unsur dalam suatu pertunjukan seperti gerak tari, busana, tembang, dan fungsi pertunjukan. Ketiga, sintren dipandang dari bunyinya seperti berhubungan dengan tantra yang berasal dari kata stuti tantra yang artinya 'nyanyian'. Dalam pertunjukan yang bermakna demikian yang bersifat ritual tujuan dasarnya adalah penyatuan antara manusia dan energi dewa yang dipujanya. Penyatuan itu terjadi pada saat trance 'penari berada dalam bawah sadar'.

Sintren yang bermakna ketigalah yang berkaitan dengan penelitian ini. Jadi, sintren adalah seni pertunjukan tari yang tumbuh dan berkembang di Indramayu. Sintren memiliki banyak versi: muncul dan latar belakangnya. 
Sesungguhnya, nama sintren tidak diketahui berasal dari mana, tetapi ia adalah seorang gadis yang menjadi tokoh utama dalam pertunjukan. Juju dalam Mulyani (2012: 95) menerangkan bahwa sintren mulai dikenal pada tahun 1940-an. Menurutnya, asal mula sintren adalah kebiasaaan kaum ibu dan putra-putranya yang tengah menunggu suami/ayah mereka pulang mencari ikan di laut.

Pertunjukan sintren tidak sekadar tari, tetapi mengandung kisah masa lalu atau mitos tentang percintaan muda-mudi pada masa Sultan Agung, Raja Mataram. Nurlelasari et al. (2017:18) mendeskripsikan munculnya sintren berdasarkan tradisi lisan yang beredar di masyarakat Indramayu. Kisah percintaan Ki Joko Bahu (Bahurekso) dengan Ramtasari tidak disetujui oleh Raja Mataram. Raja Mataram memerintahkan Bahurekso berperang melawan VOC di Batavia. Saat perpisahan dengan kekasihnya, Bahurekso memberi sapu tangan pada Ramtasari. Bahurekso gugur di medan perang. Ramtasari sangat sedih. Ia menelusuri dan melacak tempat gugur kekasihnya.

Ramtasari melakukan perjalanan melalui wilayah Pantai Utara sebagai seorang penari sintren dengan nama Sulasih. Sulasih melacak kekasihnya, bertanya ke sana-sini dengan membawa saputangan pemberian Bahurekso. Bahurekso yang sebenarnya masih hidup mencari-cari pemilik saputangan yang sangat dikenalnya. Setelah diketahui bahwa Sulasih tak lain adalah Ramtasari, Bahurekso menemui penari sintren yang ternyata kekasihnya. Mereka akhirnya hidup berbahagia.

Kemudian, kisah sintren yang juga beredar di masyarakat yang merupakan kelisanan pertama adalah kisah cinta antara Sulasih dan Raden Sulandono, putra Bupati Mataram yang bernama Joko Bahu. Hubungan itu tidak disetujui Joko Bahu. Pasangan itu berpisah. Sebelum perpisahan, Sulandono memberi saputangan pada kekasihnya. Saputangan itulah yang kelak menjadi sarana bertemunya kembali Sulasih dan Sulandono. Selama perpisahan itu, Sulasih berperan sebagai penari sintren. Saat menari itulah, Sulasih selalu kosong jiwanya dan mengalami trans.

Terlepas dari itu, sintren sebagai tradisi lisan masyarakat Indramayu yang memiliki fungsi ritual sampai saat ini masih terpelihara dengan baik, meskipun dari waktu ke waktu mengalami perubahan dari segi bentuk, teknik, dan fungsi. 


\section{Pertunjukan Sintren}

Penari sintren adalah seorang wanita, tetapi dapat pula seorang pria. Jumlah pemain bervariasi, antara 15 sampai dengan 25 orang. Menurut Dahuri Dahuri (2004: 136) mereka adalah sintren, pawang, pelawak, nayaga, dan pembantu lainnya Lalu Galba n.d. (2004:106) memperinci lebih lanjut mengenai personal ini. Penari sintren di Indramayu harus anak perempuan yang belum haid. Di daerah lain, penari sintren kadang-kadang gadis remaja yang sudah haid. Namun, saat pertunjukan terkadang gadis yang sudah haid ini agak lambat mengalami trans atau tidak dapat mengalami trans, sedangkan gadis yang belum haid akan cepat mencapai trans atau masuknya roh dan sintren akan tidak sadar.

Telah dikemukakan bahwa di antara pemain sintren terdapat nayaga. Nayaga adalah orang yang memainkan alat musik atau gamelan. Alat musik yang mengiringi sintren, antara lain ketipung, satu kendang kecil, kecrek, dan buyung. Pelengkap lain yang selalu ada, dlupok, kemenyan, bunga yang diuntai, minyak wangi, perlengkapan tari, seperti kaca mata hitam, kurung ayam yang ditutup kain batik atau samping yang digunakan saat penari ganti kostum.

Oncor atau obor atau lampu tempel menyala diiringi gamelan. Asap kemenyan mengepul. Suara gamelan mengalun. Semua berfungsi membangun suasana sakral. Sesajen lainnya seperti jajan pasar, gula aren, kolak pisang, telur ayam, kembang tujuh rupa tersaji di depan panggung. Pawang membaca mantra-mantra. Pertunjukan sintren siap digelar. Seorang penari, gadis muda belia yang akan menjadi sintren masuk mengenakan pakaian biasa. Tangan gadis itu terikat dengan kuat.

Pawang mengurung gadis itu dengan kurung ayam. Pemain lainnya menuturkan semacam mantra melalui nyanyian. Tuturan itu adalah turun sintren yang berbahasa Jawa dialek Indramayu. Dinyanyikan secara berulang-ulang. Mantra ini dituturkan berulang-ulang sebagai cerminan pemujaan pada leluhur agar menurunkan bidadari dan menitis pada gadis yang dikurung.

Turun-turun sintren

Sintrene widhadhari

Widhadhari tumuruno

Aja suwen mindh dalem

Dalem sampun kangelan
Turun-turun sintren

Sintrennya bidadari

Bidadari turunlah

Jangan lama

Lama sudah kesusahan

Nurlelasari, Herlina, \& Sofi (2017:21) 
Pawang membuka sangkar, kurung ayam. Tampaklah sintren yang sudah mengenakan kostum penari. Kaca mata hitam menutupi matanya dan tangannya bebas dari tali yang tadi mengingatnya. Sintren itu didampingi pawang yang bertugas menjaganya. Sintren perlahan-lahan menari lemah gemulai. Lama-lama sesuai dengan irama yang dimainkan, sintren menari semakin lincah. Tarian itu di antaranya menggambarkan kisah Sulasih yang mencari kekasihnya, Sulandono.

Penonton yang merasa terhibur tak segan-segan menyawer sintren, memberi uang atau ada pula yang melemparkan saputangan, kain, dan yang lainnya yang di dalamnya juga terdapat uang. Pertunjukan diselingi lawakan. Berikutnya, sintren menari kembali diiringi lagu atas permintaan penonton. Karena dalam keadaan tak sadar, sintren menari seperti tidak ada capek-capeknya.

Dalam situasi itu, pawang atau dalang sangat berperan untuk mengembalikan sintren pada situasi semula. Pawang meniupkan asap kemenyan ke wajah sintren. Mulutnya komat-kamit. Pawang menuturkan mantra berulang-ulang.
Ayo ngewer-ngewer putren
Ayo jinjing-jinjing putren
Sing dikewer rujake bae
Yang dijinjing rujaknya saja
Ayo nyawer-nyawer sintren
Ayo kita nyawer sintren
Sing disawer panjoke bae
Yang disawer nayaganya saja

Sintren berjongkok. Pawang menutup sintren dengan kurung ayam seperti awal pertunjukan. Lalu pawang menuturkan mantra lain untuk menyadarkan sintren.
Orok-orok
Orok-orok
Banyu bangrimapar tembok
Air sambil merayap dinding
Wong nonton pada udodhok
Orang nonton harus duduk
Udodhok
Duduk
Sintren metu salin erok
Sintren keluar ganti kostum

Sintren sadar kembali. Jika pertunjukan benar-benar telah selesai lagu yang dinyanyikan adalah lagu Tong-Tong Breng seperti berikut ini.

Ulung-ulung simbar wulung
Aing wulung patine laying
Ala gandrung eling-eling
Ayo si....

Ulung-ulung bulu dada

Kalo wulung matinya layung

Ala gandrung ayo ingat-ingat lagi

Ayo si......

(disebutkan nama yang menjadi sintren) pada balik (Galba (peny.), 2004: 108-109). 


\section{Sintren sebagai Secondary Orality}

Seni pertunjukan tradisi pada umumnya merupakan sosok seni pertunjukan yang sangat lentur dan "cair"e sifatnya. Artinya, tradisi itu dapat menyesuaikan diri dengan kondisi dan situasi yang terjadi di masyarakat pendukungnya. Sintren misalnya, dalam primary orality pertunjukan bersifat magis dan mengandung ritual tertentu. Namun, dalam secondary orality, sifat magis Sintren apalagi yang mengandung ritual-ritual sudah hilang. Hal tersebut karena lingkungan masyarakatnya yang selalu berada dalam kondisi yang terus berubah-ubah.

Oleh karena itu, kata Dasiharjo (2009:10) dengan perkembangan kondisi masa kini, tradisi lisan di mana pun tidak bisa lagi hanya mementingkan ekspresi diri dengan nilai-nilai yang diframe, tetapi harus lebih luas lagi memikirkan kepentingan orang banyak termasuk juga kreativitas lain yang bersumber pada tradisi lisan yang kaitannya dengan ekonomi, baik bagi para pelaku seni maupun bagi perkembangan seni itu sendiri. Ini berarti seni harus bersinergi dengan aspek atau kegiatan lain, termasuk kegiatan iklan, pertunjukan musik modern, serta penerbitan buku sebagaimana halnya dengan sintren sebagai sektor ekonomi. Kondisi ini merupakan peluang yang sangat besar bagi seni pertunjukan sintren karena dapat berfungsi sebagai objek daya tarik tertentu.

Selanjutnya, berkembangnya teknologi informasi yang luar biasa cepat, pementasan tradisi lisan suka atau tidak suka dengan sendirinya masuk dalam bisnis industri media. Dengan kata lain kekuatan industri media amat mewarnai wajah tradisi lisan masa kini yang disebut Ong sebagai secondary orality yang menjelaskan bahwa kita sudah masuk dalam kelisanan tahap kedua. Tradisi lisan tidak lagi tampil ketika penutur bertemu langsung dengan penonton/penikmatnya dalam ruang waktu dan tempat yang sama, tetapi muncul dalam kemasan rekaman video atau kaset yang dapat dihadirkan kapan pun.

Telepon, radio, televisi, dan berbagai macam media lain dan teknologi elektronik membawa kita pada era secondary orality. Secondary orality secara esensial merupakan suatu kelisanan yang lebih bersifat disengaja dan sadar diri, secara permanen didasarkan pada kegiatan tulis-menulis dan cetak-mencetak.

Dewasa ini, sintren cukup berpengaruh pada kehidupan masyarakat tidak hanya dalam hal seni pertunjukan, tetapi telah memberi inspirasi kepada sebagian 
pengusaha rokok. Pengusaha rokok khususnya yang mau peduli pada budaya seni tradisional atau pertunjukan sintren terinspirasi menjadikan sintren sebagai merek dagang dalam kemasan rokok. Proses ekonomi kreatif yang bersumber dari seni pertunjukan sintren dengan menamai sintren dalam kemasan rokok minimal dapat mengingatkan masyarakat pemilik tradisi tersebut bahwa mereka memiliki seni tradisi yang bernama sintren. Lebih luas dari itu, sintren yang tercantum dalam kemasan rokok dapat melestarikan dan mengawetkan tradisi lisan sintren.

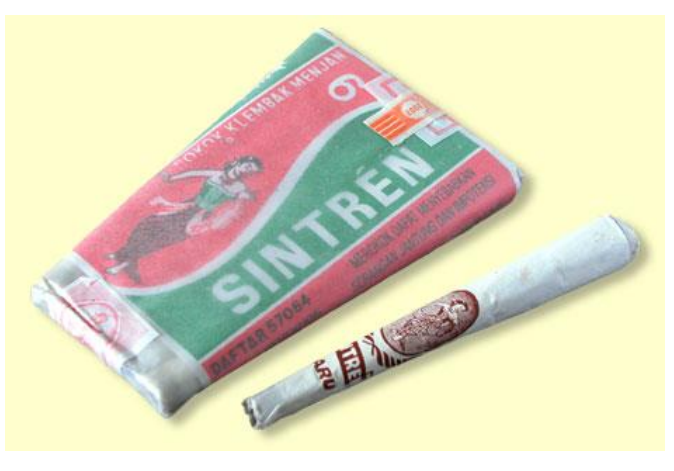

Gambar 1: Rokok klembak sintren

(Foto: diunduh dari kaskus. com)

Selain rokok, sintren juga menjadi merek dalam kemasan kertas rokok dengan nama « Kertas Sigaret Sintren Istimewa » lengkap dengan penari yang menjadi ciri khas pertunjukan sintren, seperti tampak dalam gambar berikut. Sintren sebagai seni pertunjukan secara keseluruhan telah bertransformasi menjadi sebuah merk dagang. Meskipun begitu, nama sintren dengan ikon penari yang khas dan unik tetap menghubungkannya dengan sintren dalam primary orality.

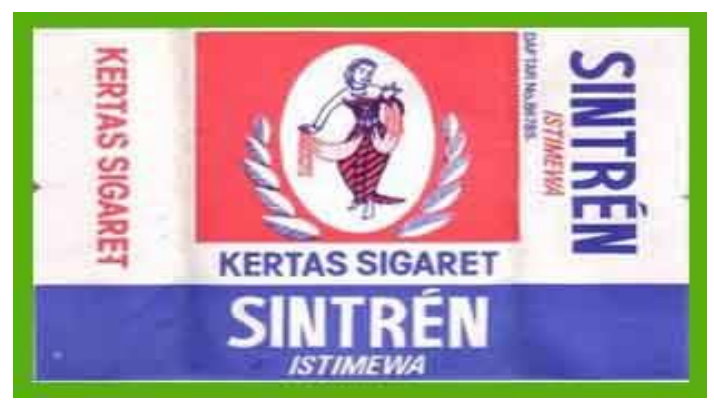

Gambar 2: Kertas Sigaret Sintren Istimewa (flifofer.blogspot.com) 
Secara esensial rokok sintren dan kertas rokok sintren merupakan suatu kelisanan yang lebih bersifat disengaja dan sadar diri, secara permanen didasarkan pada kegiatan tulis-menulis dan cetak-mencetak. Meskipun sebatas nama dan gambar yang melekat pada sebuah produk, posisi rokok, dan kertas rokok, sintren dengan ikon penari sintren tetap saja dapat dipandang sebagai secondary orality yang merujuk pada tradisi lisan sintren.

Berikutnya kertas rokok lain yang menggunakan nama sintren dan gambar penari sintren adalah kertas tembakau seperti tampak dalam gambar berikut.

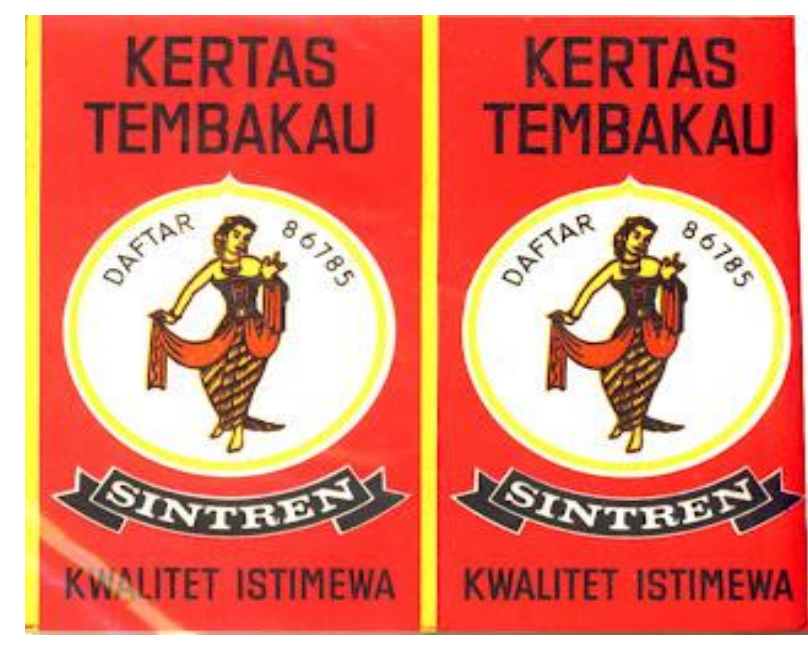

Gambar 3: Kertas Tembakau Sintren

(Foto: diunduh dari semangkukbakmie.blogspot.com)

Gambar dalam kemasan kertas rokok tersebut merupakan jenis produk kertas tembakau dan nama produk kertas tembakau sintren. Kemasan kertas rokok bermerek sintren ini telah terdaftar dengan nomor daftar legal 86785, ukuran panjang $82 \mathrm{~mm}$, lebar $45 \mathrm{~mm}$, tebal $2 \mathrm{~mm}$, warna dominan merah, teknik cetak offset, jenis kertas yang digunakan HVS, visual yang tampak seorang penari sintren. Pemilik kertas rokok yang dalam kemasannya menggunakan gambar penari sintren adalah The Gie Thoan (Agus Sugianto), dan kemudian usahanya tersebut diturunkan kepada anaknya, yaitu Edi Hendrawanto.

Sintren sebagai primary orality juga bertransformasi menjadi secondary orality dalam wujud novel dengan judul Sintren. Sintren adalah karya Dianing Widya Yudhistira diterbitkan oleh Grasindo pada tahun 2007 dengan tebal 296 halaman. Novel ini terpilih sebagai sepuluh besar novel kategori prosa Khatulistiwa Literary 
Award 2007 dalam ajang lomba bagi dunia literer yang meraih hadiah uang sebesar 100 juta rupiah dan wisata ke luar negeri bagi pemenang pertamanya. Novel Sintren karya penulis Dianing ini mampu bersaing dengan sederet penulis ternama, yaitu seperti Andrea Hirata, Akmal Nasery Basral, Cok Sawitri, Gus TF Sakai, dan Noorca M Yudisthira.

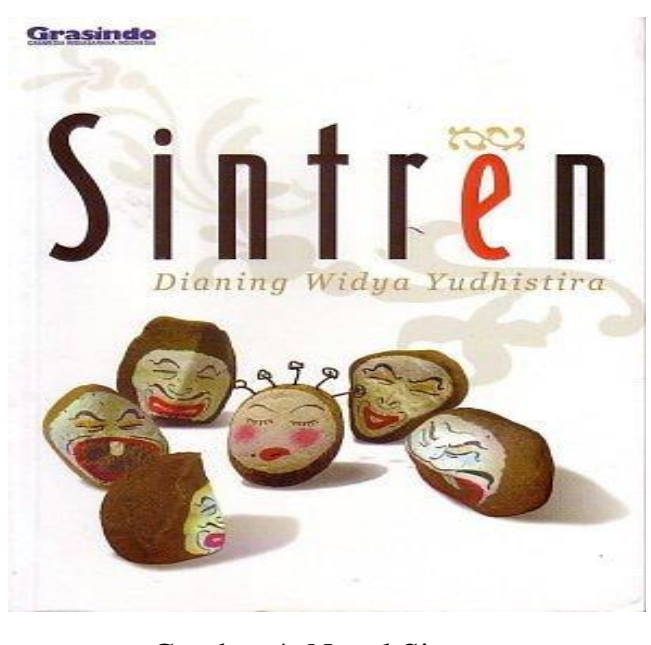

Gambar 4: Novel Sintren

Novel Sintren ini mengisahkan seorang penari sintren yang bernama Saraswati. Dia adalah gadis desa yang baru berusia 12 tahun. Ia gadis yang lugu, tetapi pintar secara akademik di sekolahnya dan memiliki tekad yang kuat untuk melanjutkan sekolah hingga SMP. Ibunya seorang buruh nelayan, sedangkan ayahnya seorang penarik becak. Kesulitan hidup membuat ibunya berusaha mengangkat derajat kehidupan mereka dengan menjodohkan Saraswati dengan Kirman, putra juragan Wargo, majikannya.

Awalnya Saraswati menolaknya karena ia masih ingin bersekolah. Namun, akibat desakan ibunya, Saraswati terpaksa menerima dirinya untuk dijodohkan dengan Kirman. Menjelang upacara pertunangan, tiba-tiba juragan Wargo membatalkan niatnya secara sepihak. Saraswati pun merasa lega dengan keputusan juragan Wargo tersebut karena dengan demikian ia masih memiliki peluang untuk melanjutkan sekolahnya. Belum lagi bisa bernafas lega, tiba-tiba Larasati yang sedang mencari penari sintren melihat bahwa Saraswati tampaknya cocok untuk menjadi seorang penari sintren. Hal itu diutarakannya kepada Ibu Saraswati. Tanpa mendiskusikannya terlebih dahulu dengan suami dan anaknya, ibunya menyetuju- 
inya dan langsung menerima uang muka sebagai tanda kesepakatan untuk menyerahkan Saraswati menjadi seorang penari sintren. Saraswati dan ayahnya tak bisa menolak keinginan ibunya. Saraswati diiming-imingi sejumlah harapan memperoleh uang banyak yang bisa dipakainya untuk melanjutkan sekolah ke SMP.

Setelah melalui proses penyeleksian yang dilakukan oleh Mbah Mo selaku pawang sintren, Saraswati dinyatakan lulus sebagai seorang penari sintren karena dari beberapa orang yang diuji hanya Saraswati yang lolos dari ujian dan tidak pingsan atau kesurupan ketika dimasukkan ke dalam kurungan ayam yang telah dijampi Mbah Mo. Saraswati berubah dari gadis yang lugu menjadi gadis yang memiliki karisma seorang penari sintren. Ia kini tak terlihat lagi sebagai seorang anak-anak. Saraswati yang tadinya seorang anak yang lugu kini tampil menjadi gadis yang percaya diri dan berani melawan kesewenang-wenangan yang diperbuat kawan-kawannya. Dia juga tampak lebih dewasa. Aura tubuhnya memancarkan keelokan dan kemolekan seorang penari sintren yang membuat banyak lelaki terpana dan ingin mempersuntingnya. Saraswati menjadi seorang penari sintren yang terkenal. Ia memperoleh banyak uang dari hasil menari. Akhirnya, cita-citanya untuk melanjutkan sekolah hingga SMP tercapai.

Kecantikan dan kepintaran menarinya itu telah memikat banyak orang. Para lelaki ingin mempersuntingnya. Tidak hanya yang bujangan, tetapi yang sudah mempunyai istri pun hendak melamarnya untuk dijadikan istri muda. Hal ini membuat para ibu kurang simpatik terhadap Saraswati. Saraswati akhirnya menerima pinangan seorang laki-laki. Namun, belum sempat menyentuh tubuh Saraswati, suaminya tiba-tiba meninggal dunia. Saraswati menjadi janda. Tidak lama kemudian ia menikah lagi. Namun, nasibnya sama seperti suaminya yang pertama. Suami Saraswati yang kedua pun meninggal sebelum menyentuhnya. Hal ini terus berulang hingga Saraswati menikah keempat kalinya. Semua suaminya harus mati mengenaskan sebelum menyentuh dirinya. Akhirnya, Saraswati tetaplah seorang gadis yang masih perawan. Ia menjadi seorang penari yang sukses dan memikat para penontonnya. Namun, ada harga yang harus dibayar. Ia dianggap telah membawa sial bagi kampungnya karena setiap lelaki yang menikahinya pasti meninggal dunia. 
Dianing menuliskan novel Sintren ini dengan kalimat-kalimat yang sederhana. Tak ada penggunaan metafora yang berlebihan dan menuliskannya dengan bahasa yang mudah dipahami. Penyajian isi ceritanya yang sederhana dan lugas menggambarkan kehidupan masyarakat pesisiran yang masih hidup tertinggal dan menggantungkan hidupnya dari hasil melaut. Kultur dan kebiasaan masyarakat nelayan mewarnai seluruh novel ini.

Dengan demikian, Dianing membawa pembacanya masuk ke dalam realitas keseharian yang terjadi di tengah masyarakat pesisiran yang lengkap dengan tradisi keseniannya, yaitu sintren. Seni sintren yang khas tradisi lisan masyarakat pesisir yang menarik perhatian masyarakat mampu dipotretnya. Dianing juga merekam denyut kehidupan penari sintren dengan berbagai sisi kehidupannya. Novel ini juga mengungkap apa yang dialami, dilihat, dan dirasakan Saraswati ketika ia sedang menari sintren.

Dikisahkan dalam novel ini bahwa jiwa Saraswati terpisah dari raganya. Raganya dipinjam oleh ruh seseorang, yaitu Den Ayu Lanjar yang membantunya menari. Hal ini menegaskan bahwa kesenian sintren dilakukan tanpa trik-trik khusus yang menipu penontonnya. Sintren seperti halnya kesenian ronggeng, tayub, reog, dan debus tidak semata dikendalikan oleh kekuatan manusia biasa, tetapi ada unsur mistis yang ikut mewarnai kesenian sintren. Hal ini dipengaruhi masyarakat Indonesia yang memiliki sejarah animisme yang berkembang jauh sebelum masuknya agama Islam.

Satu hal yang tampaknya kurang dalam novel Sintren ini Dianing tak menjelaskan dengan terperinci bagaimana kesenian sintren terbentuk. Padahal hal ini bisa diungkap melalui dialog sederhana antara Saraswari dengan Larasati atau Mbah Mo yang membimbingnya menjadi seorang penari sintren. Jika saja hal ini diungkap pembaca pasti akan memperoleh wawasan baru mengenai latar belakang kesenian sintren.

Novel ini juga tak menjelaskan mengapa Saraswati yang sama sekali tak memiliki darah seniman tiba-tiba bisa menjadi penari sintren yang sukses. Novel ini hanya mengungkap bahwa sintren yang ada dalam tubuh Saraswati adalah sintren Den Ayune Lanjar, sintren sakti yang memiliki kecantikan luar biasa. Tentunya akan lebih menarik jika diberikan penjelasan apa keistimewaan Saraswati sehingga 
Den Ayu Lanjar memilih tubuh Saraswati untuk dirasukinya agar menjadi penari sintren.

Novel Sintren secara umum tidak terlalu menunjukkan perbedaan yang mencolok. Ide cerita yang terbangun tidaklah jauh dari sintren sebagai tradisi lisan. Meskipun di sana-sini terdapat pengembangan, novel Sintren dapat ditemukan persamaan, misalnya judul novel Sintren adalah unsur pertama yang menarik perhatian khalayak yang bertujuan untuk membangun hubungan antara pembaca dengan kisah yang sudah menjadi milik masyarakat. Dengan demikian, akan terjadi jalinan antara tema novel dan khalaknya. Ketika membaca novel tersebut, pembaca akan menggunakan sintren dalam tradisi lisan sebagai referensi untuk memahami novel tersebut.

Latar belakang Larasati menjadi penari sintren sebagai tokoh utama dalam novel Sintren, relatif serupa Sulasih dalam kisah pertunjukan sintren. Karakter yang digambarkan juga nyaris sama. Jalan cerita juga dibangun dengan alur sederhana, bukan sesuatu yang rumit. Meskipun begitu, sintren sebagai kelisanan kedua yang berupa teks, pemahaman isinya sangat bergantung pada daya emosional seorang pembaca terhadap sebuah teks dan kemampuan pembaca memiliki imajinasi terhadap teks bacaan.

Namun, bagaimana pun novel Sintren yang sebelumnya pernah dimuat bersambung di Harian Republika pada tahun 2005 ini patut diapresiasi dengan baik. Di tengah-tengah ragamnya tema-tema novel yang diangkat seperti tentang budaya, sosial, dan politik, ternyata kehadiran novel Sintren telah mengangkat tema budaya tradisi lisan sebagai upaya pelestarian tradisi lisan, khususnya dalam hal seni sintren.

Novel Sintren yang dipandang sebagai kelisanan kedua merupakan sebuah produk unik dari budaya tulis yang sekaligus menggunakan kembali beberapa karakteristik budaya lisan. Novel tersebut sebagai kelisanan kedua hadir sebagai transformasi teknologi yang mengambil alih fungsi penyampaian informasi dan komunikasi dengan memanfaatkan bentuk teks. Selain itu, kelebihan kelisanan kedua, novel Sintren penikmatannya tidak terbatas ruang dan waktu, sedangkan pertunjukan sintren sebagai kelisanan pertama harus tampil pada waktu dan tempat 
tertentu. Dengan diterbitkannya novel Sintren berdampak positif bagi kelangsungan seni tradisi lisan tersebut.

Selain itu kelisanan kedua yang diilhami dari seni sintren buhun tidak hanya dalam hal penerbitan. Kreativitas sintren muncul dengan hadirnya para seniman yang berkreasi untuk mengembangkan sintren dalam versi modern. Irama dangdut mewarnai pertunjukan sintren yang akhirnya disebut dengan sebutan sintren dangdut seperti yang ada di daerah Indramayu.

Sintren sebagai seni pertunjukan tradisi juga bertransformasi menjadi seni pertunjukan modern. Irama dangdut mewarnai pertunjukan sintren yang akhirnya disebut dengan sebutan sintren dangdut. Sintren dangdut adalah perpaduan seni sintren buhun dengan ditambah alat-alat musik modern dan dengan nyanyian lagulagu dangdut. Hal ini seperti terlihat dalam salah satu grup sintren yang telah manggung dan sering mengadakan pementasan, baik di Indramayu maupun di wilayah Jawa Barat. Bahkan sintren dangdut ini permah diundang ke luar negeri untuk mengadakan pementasan. Sintren berkembang juga di kalangan remaja dengan lahirnya sintren dance kontemporer, yaitu menggabungkan tarian sintren dengan dance (tarian barat). Sintren dance ini berkembang di daerah Pekalongan seperti dalam gambar 5 .

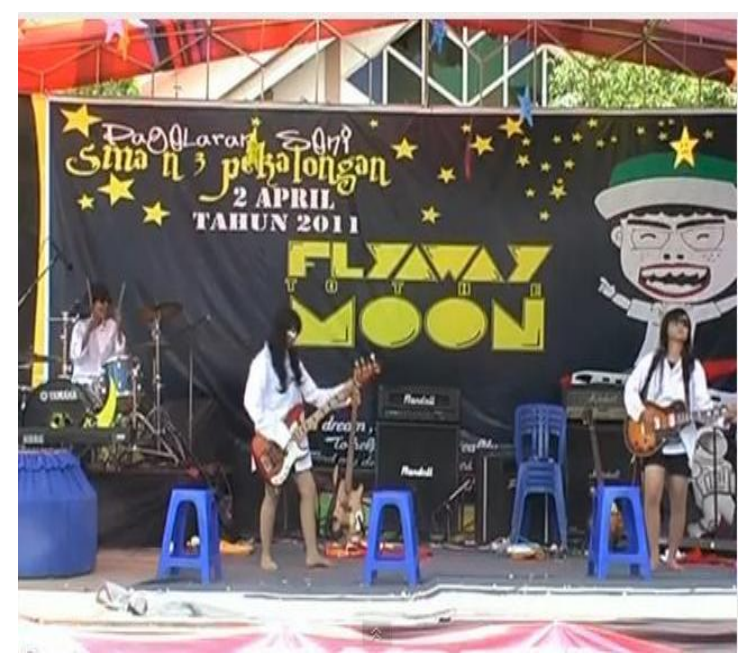

Gambar 5: Sintren Dance Kontemporer, SMAN 3 Pekalongan, (Foto: Diunduh dari youtube. Com)

Di samping itu, muncul aliran sintren modern, yaitu kolaborasi musik tradisional dan musik modern dan dalam pertunjukannya tetap menggambarkan ciri 
khas sintren, yaitu menghadirkan kurung ayam sebagai simbol pertunjukan sintren yang akan mengurung penari sintren.

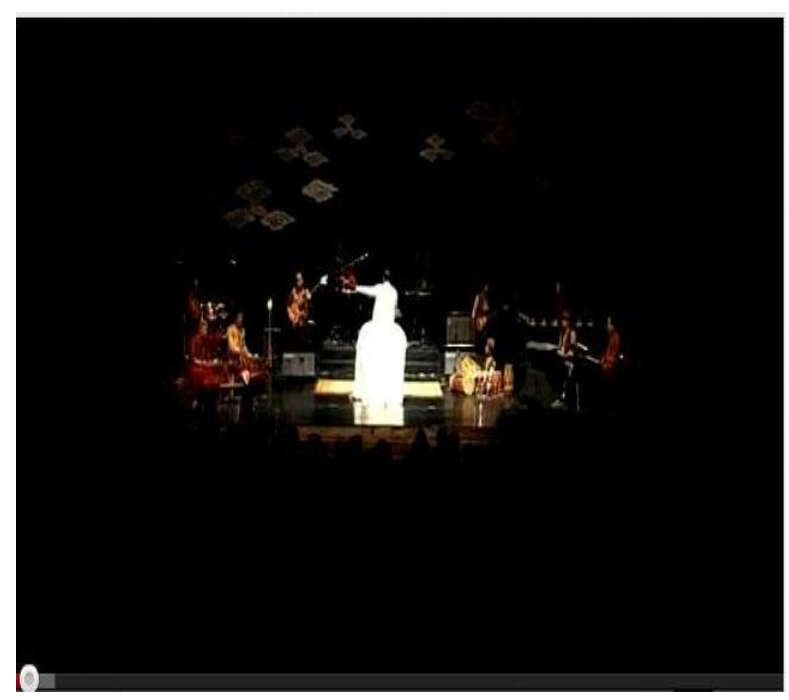

Gambar 6: Sintren modern (diunduh dari koprol. Com)

Jika dalam secondary orality sebagaimana dalam novel Sintren yang lebih mengedepankan aktivitas pembacaan yang cenderung soliter, pertunjukan sintren modern menggunakan sumber suara dalam menyampaikan informasi. Secondary orality dalam sintren modern mampu mengakomodasi budaya sebelumnya, yaitu budaya lisan dan budaya tulis.

Jika dalam primary orality, pertunjukan sintren lebih bersifat seremonial, bernuasa magis, asap kemenyan, dan mantra-mantra dengan ruang waktu terbatas, setelah bertransformasi sebagai secondary orality sintren meninggalkan karakteristiknya dan lebih mengedepankan teknologi.

Pertunjukan sintren yang dimediasi media modern seperti sintren dalam bentuk VCD dan CD atau muncul di radio dan televisi. Meskipun terbatasnya penonton atau penikmat yang terlibat secara aktif, sintren dalam secondary orality tetap merupakan salah satu cara untuk mengawetkan tradisi lisan.

\section{SIMPULAN}

Sintren adalah tradisi lisan yang penyampaiannya berupa pertunjukan tari dan pembacaan mantra-mantra dipandang sebagai kelisanan pertama. Dalam perjalanannya sintren telah mengalami transformasi ke dalam berbagai bentuk seperti menjadi nama untuk sebuah kemasan rokok atau merk dagang kertas rokok, sebagai sebuah 
novel modern, sebagai pertunjukan musik dalam sintren modern, dan hadir dalam kemasan VCD, CD, serta tampil dalam radio dan televisi.

Sebagai kelisanan kedua dengan tampilan baru yang hadir dalam merek dagang, novel, dan sintren modern tidak meninggalkan ciri dan karakteristik sintren dalam kelisanan pertama. Meskipun demikian, novel yang berjudul Sintren sebagai kelisanan kedua mampu mengawetkan dan melestarikan tradisi sintren. Demikian pula dengan nama sintren yang tampil dengan penari sintren dalam kemasan rokok bagi siapa pun khususnya yang mengenal tradisi sintren akan selalu mengingatkan bahwa kita mempunyai seni tradisi pertunjukan yang bernama sintren.

Berdasarkan indikator karakteristik, baik dalam budaya tulis maupun kelisanan kedua, ditemukan bahwa terjadi pembacaan dan pemaknaan yang berbeda antara sintren sebagai kelisanan pertama dan atas novel dan pertunjukan musik sintren modern. Novel Sintren, kemasan rokok sintren, dan pertunjukan musik sintren modern sebagai bentuk kelisanan kedua mampu menjawab persoalan keterbatasan pembacaan kisah penari sintren bentuk novelnya dan pertunjukan musik modern.

Kekuatan visual yang terdapat dalam bentuk pertunjukan musik modern dan tidak adanya aroma mistis serta terbebasnya pertunjukan dari ruang waktu memungkinkan penonton terlibat dan tiada berjarak dengan kisah yang termuat di dalamnya sehingga penonton jauh lebih paham. Dengan demikian, sintren dalam bentuk secondary orality dari segi bentuk benar-benar berubah, sedangkan dari substansi tidak terlalu banyak berubah. Sintren dalam secondary orality masih dapat dilacak jejaknya.

\section{DAFTAR PUSTAKA}

Bahardur Iswadi. (2018). Kearifan Budaya Minangkabau Dalam Seni Pertunjukan Budaya Randai. Jentera, 7 (2), 145-160, (C2018. DOI 10.26499/jentera.v7i2.932

Dahuri, R. (2004). Budaya bahari : Sebuah Apresiasi di Cirebon. Jak: Percetakan Negara.

Damono, S. D. (2015). Sastra, Citizen, Netizen (pp. 1-12). Jak: FIB Universitas Indonesia.

Dasiharjo, M. . (2009). Pengembangan Potensi Seni Tradisi di Jawa Barat Melalui Pembinaan Sentra-Sentra Budaya. Bandung.

Endraswara, S. (2009). Metodologi Penelitian Folklore: Konsep, Teori, dan Aplikasi (ke-1). Yogyakarta: Media Presindo. 
Galba, S. (n.d.). Budaya Tradisional Pada Masyarakat Indramayu. Indramayu.

Kasim, S. (2013). Budaya Dermayu: Nilai-Nilai Estetis, dan Transendental. Indramayu.

Mulyani, Y. (2012). Revitalisasi Tradisi Lisan Sunda dan Pemanfaatannya untuk Pengembangan Industri Pariwisata dan Industri Kreatif di Jawa Barat. B.

Nurlelasari, D., Herlina, N., \& Sofi, K. (2017). Seni Pertunjukan Sintren di Kabupaten Indramayu dalam Perspektif Historis. Panggung, 27(Maret 2017), $15--25$.

Ong, W. J. (1982). Orality and Literacy The Technologizing of the Word. (N. Y. Routledge, Ed.). London and New York.

Rahman. (2011). Kelisanan dalam Tradisi Maata Pada Masyarakat Laporo di Kabupaten Buton. Universitas Indonesia.

Sabana, S. dan H. S. (2005). Legenda Kertas: Menelusuri Jalan Sebuah Peradaban (p. 3326). Bandung: Kiblat Buku Utama.

Suryadi. (2011). Tradisi Lisan dalam Perspektif Kajian Agama. Denpasar.

Triwardani, R., \& Wicandra, O. B. (2002). Literacy And Secondary Orality: (Sebuah Analisis Perbandingan Kisah Romantis "A Walk to Remember " Versi Novel dan Film ). Kajian Budaya Dan Media Universitas Gadjah Mada, Yogyakarta, 37-44.

Venturini, T., Nielsen, R. K., International, E., \& Dictionary, C. (1983). Secondary Orality ( or second orality ).

\section{Internet}

https://fjb.kaskus.co.id/product/539161f1a1cb17982e8b4672/rokok-sintren-klembak-menjan-rokok-menyan-pecinta-rokok-masuk. Diunduh pada tanggal 25 September 2012, pukul 09.29 WIB.

https://books.google.co.id/books?id=FD3OLnATK5kC\&pg=PA148\&lpg=PA148 $\& \mathrm{dq}=$ Novel+ Sintren $+($ Grasindo $) \&$ source $=\quad=$ Novel\%20Sin tren\%20(Grasindo)\&f=false. Diunduh pada tanggal 15 Januari 2019, pukul 14.10 WIB

https://www.google.com/search?client=firefox-b-d\&q=Sintren+Dance+Kontemporer\%2C+SMAN+3+Pekalongan. Diunduh pada tanggal 5 Maret 2109, pukul $19.00 \mathrm{WIB}$. 